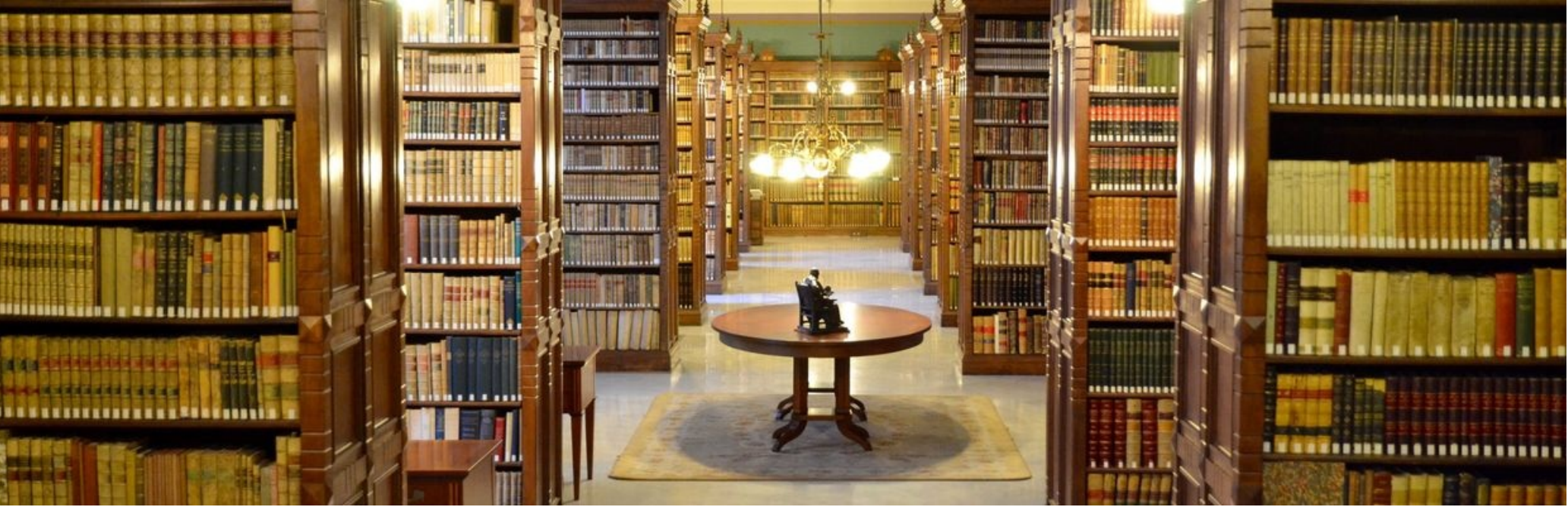

\title{
Editorial Volume 6, Issue 8
}

$\begin{aligned} \text { Authors: } & \text { María Fernanda Sandoval } \\ \text { Submitted: } & \text { 3. September } 2019 \\ \text { Published: } & \text { 3. September } 2019 \\ \text { Volume: } & 6 \\ \text { Issue: } & 8 \\ \text { Affiliation: } & \text { IASHA e.V., Freiburg, Germany } \\ \text { Languages: } & \text { English } \\ \text { Keywords: } & \text { Editorial, Josha Journal, 2019, August } \\ \text { Categories: } & \text { News and Views } \\ \text { DOI: } & 10.17160 / \text { josha.6.8.597 }\end{aligned}$

Abstract:

This summer editorial is notable for containing articles of great interest. First, we find a brief summary of what was the night of the Demetrios awards, covering the awards ceremony to its winners for the presentation of research work belonging to different disciplines and also in different languages. Followed by this summary we presented you two publications in the area of medicine and science with topics of high interest, as well as two more articles in the categories of music and society. One of them constitutes the current line of columns published until now by Dr. Hotaki around classical music and the other represents our first article in the form of a report and social criticism, hand in hand with a real testimony

\section{JOSHA Jouna ofsemeree Humanities and Arts




\section{JOSHA - Journal of Science Humanities and Arts Editorial Volume 6 Issue 8}

This summer editorial is notable for containing articles of great interest. First, we find a brief summary of what was the night of the Demetrios awards, covering the awards ceremony to its winners for the presentation of research work belonging to different disciplines and also in different languages. Followed by this summary we presented you two publications in the area of medicine and science with topics of high interest, as well as two more articles in the categories of music and society. One of them constitutes the current line of columns published until now by Dr. Hotaki around classical music and the other represents our first article in the form of a report and social criticism, hand in hand with a real testimony.

\section{NEWS \&VIEWS}

“Bright minds for a better world! Der wundervolle Abend der Demetrios Preis Verleihung 2019!'. The theses published in the journal the last weeks are bachelor, master and doctoral theses by young scientists. The spectrum ranges from philosophy and cultural studies to machine learning and medical work. The Pythagoras prizes went to the youth big band "Swing Kids", the poetess Zazie-Charlotte Pfeiffer and the singer Marie Brendle. All of them presented their performances at the award ceremony. Although no all of the winners were able to attend this evening, they have prepared a short video for all the readers of the Journal with an excellent explanation concerning the topics of their works. All these videos have direct access to YouTube just by clicking on the

\section{Download PDF}

Watch Video button "Watch Video".

\section{VISUAL ARTS, ARCHITECTURE, AND LITERATURE}

„Exklusive Digitalität - Exclusive Digitality“ is one of the many columns presented by Leander Hotaki. Hi is since 2010 the director of the German program called "Albert Konzerte" which is a program in charge of making possible to bring the greatest artist of the World to Freiburg and to make the most wonderful concerts in the southwest of Germany. In fact, he also promotes the work of the best students in the field of dramaturge or music in many universities in Germany and writes columns about different topics around music and musicians. This time he writes about an impressive digital music mediation on the net: "Idagio" is an exciting project that treads sensational new paths of artistic interpretation itself.

\section{MEDICINE AND MACHINE LEARNING}

„Erleben wir eine Renaissance des Lamarckismus? - Are we experiencing a renaissance of Lamarckism?" is the title of a very impressive article about the theory of Lamarckism. Horst Kress, the author,presented this as the preceding second essay on the Renaissance of Lamarckism (JOSHA Journal Vol. 4, Issue 6) where they were 
Journal of Science, Humanities and Arts

able to follow how the Sutton-Boveri chromium moment theory of inheritance achieved a grandiose breakthrough through the works in the fly-room of T. H. Morgan with the help of the fruit fly Drosophila melanogaster. The second articles of this category is a medical report published by Katja Zirlik and Roland Mertelsmann. They entitled the article "Unravelling the syndrome of age-associated diseases 2: Targeting autoimmunity with antiCD20 antibodies to reduce age-associated diseases" which is about the antibody Rituximab that was originally used to treat non-Hodgkin's lymphoma or chronic lymphocytic leukemia and was also found to be effective for all autoimmune diseases studied so far. This raises the question of whether successful treatment of autoimmune reactions, even at the subclinical level, can reduce the risk of cardiovascular disease, cancer, and other ageassociated diseases.

\section{SOCIAL \& LAW}

„Immigration Policy in Malaysia and My Eight Horrendous Days in Detention “ is our first contribution to the world press in what a social experience concern. This article was conceived by Mike Omilusi, who is a political scientist. In the course of his career as a lecturer and pro-democracy activist, he has traversed over 50 countries across different continents. Hence, he has taken the routine details of international travel for granted - until his traumatic experience in Malaysia where he was detained under extremely dehumanizing conditions for eight days in November 2017. His offense was that he failed to get a transit visa to go from one airport in the country to another. Dr. Mike Omilusi is an Independent Democracy Monitor, Freelance Journalist, Development Worker, and University Teacher in Nigeria.

We are happy to carry on a successful way with all your support and hope to have a wonderful Sommer overflowing with endless interesting articles from all over the world. Together, we have achieved so much exile in such a short time. Therefore, we thank you and promise to continue to work to connect more authors around the world and continue to share important knowledge, because the knowledge that is not communicated is wasted knowledge!

The Editorial Board and everybody in JOSHA would like to thank our readers and authors for supporting this project. We wish all our readers a joyful reading experience at JOSHA!

Table of content: http://josha-journal.org/en/issues

Maria Sandoval on behalf of the JOSHA Team 